\title{
Characteristics of Ruminal Fatty Acids Using In Vitro Culture System by Addition of Galangal (Alpinia galangal) Essential oil
}

\author{
Dewi Ratih Ayu Daning ${ }^{1,2}$, Chusnul Hanim ${ }^{1}$, Budi Prasetyo Widyobroto ${ }^{1}$, \\ and Lies Mira Yusiati ${ }^{1 *}$ \\ ${ }^{1}$ Faculty of Animal Science, Universitas Gadjah Mada Jl. Fauna No.03, Karang Gayam, Caturtunggal, Kec. Depok, \\ Kabupaten Sleman, Daerah Istimewa Yogyakarta 55281 \\ ${ }^{2}$ Politeknik Pembangunan Pertanian Malang. Jl.Dr. Cipto 144 a, Bedali, Lawang.Malang 65200 \\ *Corresponding author. Email: liesmira@ugm.ac.id
}

\begin{abstract}
Galangal essential oil (EO), which contains secondary metabolites such as cineol, hopefully can modify bacteria, causing biohydrogenation. The purpose of this study was to determine the effect of galangal EO dose on the fatty acids characteristics at in vitro rumen fermentation. Galangal as a source of EO was obtained from the local market and then extracted by steam distillation method. The phytochemical compounds of galangal were evaluated using gas chromatography-mass spectrophotometry. Each treatment consisted of the same basal feed (60\% elephant grass and $40 \%$ concentrate) with varying doses of galangal EO as much as 0 (control), 30,60,120 $\mu \mathrm{L}$ and pure cineol as much as $5 \mu \mathrm{L}$. After 48 hours of in vitro rumen fermentation, the fermated media was harvested for its fatty acid analysis by gas chromatography. The data obtained were analyzed for variance using a completely randomized design with five treatments and six replications. The concentration of MUFA (oleic acid) increased significantly by $22.16 \%, 43.09 \%$, and $42.19 \%$ compared to control at.60 and $120 \mu \mathrm{L}$ doses of EO galangal, respectively. PUFA concentrations did not significant $(\mathrm{P}>0.05)$ between galangal $\mathrm{EO}$ at doses of 0 (control) and $30 \mu \mathrm{L}$ and decreased significantly $(\mathrm{P}<0.05)$ at doses of 60 and $120 \mu \mathrm{L}$. The addition of EO galangal $60 \mu \mathrm{L}$ showed higher oleic acid concentration than $5 \mu \mathrm{L}$ pure cineol, although both treatmens has the same cineol content. The addition of $5 \mu \mathrm{L}$ of pure cineol showed that the PUFA concentration did not significant $(\mathrm{P}>0.05)$ from the control (without galangal EO). This study concluded that galangal essential oil increased unsaturated fatty acids levels with the optimum dosage of $60 \mu \mathrm{L}$
\end{abstract}

Keywords: Galangal essential oils, poly unsaturated fatty acids, cineole, in vitro rumen fermentatio

\section{INTRODUCTION}

The consumption of milk products with high content of saturated fatty acids is caused to coronary heart disease [1]. Fatty acids in dairy milk consist of saturated fatty acids (SFA), monounsaturated fatty acids (MUFA) and polyunsaturated fatty acids (PUFA) as much as $63 \%, 30 \%$, and $7 \%$, respectively. Based on feed composition in dairy cows, milk contain high of polyunsaturated fatty acids [2]. Forage in dairy feed rich in linolenic (cis-9, cis-12, cis-15 18:3). In contrast, concentrate rich in linoleic acid and oleic acid (cis-9 18:1) [3]. Although the proportion of PUFA in the feed is high, when it enters the rumen will undergo to biohydrogenation process and change into saturated fatty acids.
The biohydrogenation in the rumen involves several biochemical processes that occur. Microbial lipases hydrolyze the ester bonds in dietary lipids, and lipolysis is first step for the biohydrogenation of unsaturated fatty acids. Several types of rumen bacteria that have lipase enzyme activity are Anaerovibrio lipolyca and Butirivibrio fibrisolvens [4][5]. Strategies to reduce the biohydrogenation process have been widely reported, one of which is by using secondary metabolites such as phenolic compounds [6-8]. According to research [9][10] tannins which are also phenolic compounds, can decrease the concentration of linoleic and oleic acids. The effect of biohydrogenation by adding phenol may be due to its antibacterial activity against $B$. fibrisolvens [7]. Furthermore, [11] reported that 
phenolic compounds in the presence of a hydroxyl group could bind lipase enzyme activity.

Essential oils have been widely explored for fat protection in the rumen by inhibiting the types of bacteria that cause biohydrogenation [12][13][14]. Essential oils consist of various kinds of bioactive compounds, and more than 200 types have been identified [15]. The function of essential oils as antibacterial depends on the major compounds, but it is possible that the minor compounds also have a synergetic effect [16]. Galangal EO is one of the products made from a local plant from Indonesia and is known to function as an antibacterial. Galangal essential oil consists of various of bioactive compounds, such as cineole, phenol, and alkaloid [17]. Based on [18] cineole, phenol, and other monoterpenes compounds in galangal EO are predicted to modify the cell membrane, permeability, and alter various intracellular functions. The hydroxyl group of phenol can bind to enzymes that bacteria secreted. Based on function and bioactive of galangal EO have potential for bacterial rumen modification. This study aims to evaluate the characteristics of rumen fatty acids with galangal essential oil by in vitro rumen fermentation.

\section{MATERIALS AND METHODS}

\subsection{Galangal essential oils preparation.}

The galangal rhizome harvested from a local farmer in Boyolali district, Central Java. The rhizome has been sliced thin as much as $20 \mathrm{Kg}$ and dried at room temperature for three days until the water content decreases by $65 \%$. The dried galangal put into a steam distillation device equipped with a condenser, then heated. The water flowed into the condenser and kept flowing. Condenser temperature kept cool so that all the evaporated oil is condensed and does not escape into the air. The water and oil components separated via Clevenger-type apparatus. The distillation process lasts for 5 hours [19]. The cineol content by GC-MS analysis in galangal essential oil was used to determine the dosage of adding galangal essential oil to dairy cattle feed in vitro.

\subsection{In vitro ruminal fermentation parameters.}

The feeds was analysed by in vitro rumen fermentation from 5 treatments, namely mott elephant grass: concentrate $60: 40 \%$ (control), $30 \mu \mathrm{L}$ of galangal $\mathrm{EO} / 300 \mathrm{mg}$ dry matter of feed, $60 \mu \mathrm{L}$ of galangal EO $1300 \mathrm{mg}$ dry matter of feed, $120 \mu \mathrm{L}$ of galangal EO/300 $\mathrm{mg}$ dry matter of feed, $5 \mu \mathrm{L}$ of pure cineole/300 mg of dry matter of feed. Cineole ( $99 \%$ purity) was from SIGMALDRICH. Commercial concentrate came from Cooperative Agro Niaga Jabung, Malang. Nutrient and fatty acids composition of basal feed are presented on
Table 1. All animal procedures were licensed by Ethics Committee of Faculty of Veterinary Medicine, Universitas Gadjah Mada Number of Letter: 0055/ECFKH/Eks./2020.

In vitro rumen fermentation was conducted using a 2 -stage in vitro method (Tilley and Terry 1963) in six replications for each dietary treatment. Artificial saliva (McDougall's solution) was mixed with rumen fluid in a ratio of 4:1. Furthermore, $50 \mathrm{ml}$ of McDougall's solution was placed into a sample tube that contained $0.50 \mathrm{~g}$ of basal feed and various doses of galangal EO. All treatments were incubated into an in vitro tube 100 $\mathrm{mL}$, flowed with $\mathrm{CO} 2$ gas, and sealed with a rubber cork equipped with a gas relief valve. After $48 \mathrm{~h}$ of incubation, the sample substrate was filtered apart with rumen fluid. The filtrate was used for the analysis of fatty acids profile by gas chromatography methods.

\subsection{Experimental design.}

The data on the characteristics of fatty acids in the rumen were analysed for variance using a completely randomized design with a one-way pattern with five treatments and six replications. The software used to analyse the data was SPSS 16.

\section{RESULTS AND DISCUSSION}

Two hundred thirty bioactive compounds from galangal EO have been identified by using GC-MS. The highest percentages of bioactive consist of cineole, farnesene, B-pinene, phenol, phenyl, and eugenol with $24.38 \%, 12.19 \%, 8.48 \%, 6.01 \%, 3.00 \%$, respectively. According to research [18] [17] the components of galangal essential oil are non-polar, and the $\mathrm{OH}$ (hydroxyl) group can penetrate cell walls and cell membranes of prokaryotic cells. The hydroxyl group of phenolic compounds also can bind to bacterial polysaccharides and phospholipids, resulting in changes in cell structure, and over time, the cells will undergo lysis [20]. Cineole is the main component of galangal essential oil which belongs to the ether group with the -O- functional group attached to two alkyl groups ( $\mathrm{R}^{\prime}$ and $\left.\mathrm{R}^{\prime}\right)$. The active ether group also has a similar mechanism as phenol in reducing bacterial activity [21][22]. According to [16] mode of action of essential oils is synergistic between one component and other components, not only depending on the main element.

Screening of bioactive galangal EO was used as the basis for determining the dose in the in vitro fermentation treatment. The characteristics of the fatty acid profile of rumen fermentation are showed in Table 1. The supplementation of galangal EO at doses of 30.60 and $120 \mu \mathrm{L}$ decreased significantly on SFA levels of $5.56 \%, 11.61 \%, 9.86 \%$, respectively, compared to control. The concentration of MUFA 
(oleic acid) increased significantly by $22.16 \%, 43.09 \%$, and $42.19 \%$ at 30.60 and $120 \mu \mathrm{L}$ doses of galangal EO compared to control, respectively. PUFA concentrations did not significant $(\mathrm{P}>0.05)$ between doses of galangal EO 0 and $30 \mu \mathrm{L}$ and decreased significantly $(\mathrm{P}<0.05)$ at doses of 60 and $120 \mu \mathrm{L}$. Based on results that Galangal essential oil can reduce SFA levels than controls. The reason of possibility namely through inhibition of lipase enzyme and reduce the population of lipolytic bacteria. The higher proportion of MUFA to SFA indicates enhances the quality of beef products [23]

According to [24], the lipolysis process is the initial stage of the biohydrogenation of fatty acids. $85 \%$ fat is hydrolysed to free fatty acids, sugars, phosphates and glycerol. The rumen bacteria that cause lipolysis are Anaerovibrio lipolytica and Butyrivibrio fibrisolvens because they can secrete lipase, galactosidase and phospholipase enzymes [5]. Strategies to reduce lipolysis can be done by using phenol compounds because the hydroxyl group can bind lipase. Based on our observations of the activity of rumen fermentation enzymes in vitro, galangal EO causes a decrease in cellulolytic and amylolytic enzymes (unpublished data), so it is strongly suspected that lipase enzymes also decrease their activity. In addition, it is also known that the phenol content in galangal EO is $6.01 \%$.
Total Unsaturated fatty acids (UFA) increased by $13.79 \%, 22.53 \%, 25.24 \%$ at a dosage of galangal EO 30, 60, and $120 \mu \mathrm{L}$ compared to the control, respectively. Furthermore, cineole levels did not affect total UFA compared to controls. Unsaturated fatty acids (UFA) both MUFA and PUFA will undergo biohydrogenation by rumen bacteria. [25] reported that $70 \%$ of total oleic acid was lost in the rumen and then converted to vaccenic acid and stearic acid, and 30\% converted to hydroxy stearic acid and keto stearic acid. The type and abundance of bacteria will also affect the characteristics of the ruminal fatty acids. Butyrivibrio $s p$ is reliable for the hydrolysis of phospho- and galactolipids, while Anaerovibrio lipolytic correlated with caprylic caproic and lauric fatty acid production acids [26] [27]. The study reported that caproic and lauric levels decreased significantly $(\mathrm{P}<0.05)$ with galangal EO (Table 2). Several studies reported that C18:0 decreased significantly by the addition of using essential oils with cineole as the main component, such as rosemary and sage, in rumen fermentation in vitro [28][29]. This study also noted that it had little or no effect on the concentration of conjugated linoleic acid (CLA), linoleic, and linolenic acids. [5] reported that EOs with monoterpene as the main component, such as limonene and carvone, led to higher c9t11 CLA than controls. In addition, [30] reported that phenol as a bioactive compound of EO can inhibit the activity of Butyrivibriofibrisolvens and Butyrivibrio proteoclastic.

Table 1. Characteristics of fatty acids from rumen fermentation in vitro

\begin{tabular}{|c|c|c|c|c|c|}
\hline \multirow[t]{2}{*}{$\%$ Fatty acids } & \multicolumn{4}{|c|}{ Dosage of galangal essential oils/300 mg dry matter of feed } & \multirow{2}{*}{$\begin{array}{l}\text { Dosage of } \\
\text { cineole } \\
5 \mu \mathrm{L}\end{array}$} \\
\hline & $0 \mu \mathrm{L}$ & $30 \mu \mathrm{L}$ & $60 \mu \mathrm{L}$ & $120 \mu \mathrm{L}$ & \\
\hline Caproic & $15.03^{c} \pm 1.70$ & $8.02^{b} \pm 0.48$ & $3.89^{\mathrm{a}} \pm 0.73$ & $6.02^{b} \pm 0.89$ & $16.86^{\mathrm{c}} \pm 1.16$ \\
\hline Caprilic & $2.69^{\mathrm{a}} \pm 0.75$ & $2.83^{\mathrm{a}} \pm 0.39$ & $3.08^{\mathrm{a}} \pm 0.32$ & $3.68^{\mathrm{a}} \pm 0.32$ & $4.84^{b} \pm 0.90$ \\
\hline$(\mathrm{C} 10: 0)$ & $2.72^{b} \pm 0.57$ & $3.15^{b} \pm 0.41$ & $2.68^{b} \pm 0.30$ & $0.73^{\mathrm{a}} \pm 0.16$ & $2.66^{\mathrm{b}} \pm 0.32$ \\
\hline (C12:0) & $12.79^{b} \pm 2.00$ & $9.71^{\mathrm{a}} \pm 1.01$ & $10.23^{a} \pm 0.40$ & $10.87^{\mathrm{ab}} \pm 0.18$ & $9.03^{a} \pm 0.59$ \\
\hline Trydecylic $\quad$ (C13:0) & $1.56^{c} \pm 0.37$ & $1.19 \mathrm{bc} \pm 0.20$ & $0.68^{\mathrm{a}} \pm 0.08$ & $1.18^{b c} \pm 0.23$ & $1.01^{\mathrm{ab}} \pm 0.19$ \\
\hline Myristic & $7.11^{\mathrm{ab}} \pm 0.45$ & $6.85^{\mathrm{ab}} \pm 0.48$ & $6.94^{\mathrm{ab}} \pm 0.43$ & $7.49^{b} \pm 0.22$ & $6.38^{a} \pm 0.52$ \\
\hline Pentadecylic (C15:0) & $1.47^{a b} \pm 0.15$ & $1.57^{a b} \pm 0.17$ & $1.18^{a} \pm 0.47$ & $1.91^{b} \pm 0.42$ & $1.36^{\mathrm{ab}} \pm 0.04$ \\
\hline Palmitate $\quad(\mathrm{C} 16: 0)$ & $25.78^{a} \pm 1.15$ & $31.63^{c} \pm 1.27$ & $31.81^{c} \pm 0.65$ & $30.58^{c} \pm 1.12$ & $27.78^{\mathrm{b}} \pm 0.72$ \\
\hline Myristoleate $\quad(\mathrm{C} 14: 1)$ & $2.77^{c} \pm 0.19$ & $2.02^{b} \pm 0.05$ & $1.25^{\mathrm{a}} \pm 0.12$ & $1.00^{\mathrm{a}} \pm 0.09$ & $2.42^{b c} \pm 0.43$ \\
\hline Palmitaloate $\quad(\mathrm{C} 16: 1)$ & $1.27^{\mathrm{a}} \pm 0.22$ & $3.03^{b} \pm 0.27$ & $4.12^{c} \pm 0.76$ & $3.37^{b c} \pm 0.81$ & $1.10^{\mathrm{a}} \pm 0.06$ \\
\hline$(C 18: 1)$ & $14.22^{\mathrm{a}} \pm 1.05$ & $18.27^{b} \pm 1.16$ & $24.99^{c} \pm 1.85$ & $24.60^{c} \pm 0.63$ & $16.28^{a b} \pm 2.68$ \\
\hline Linoleat & $3.09^{b} \pm 0.27$ & $3.15^{b} \pm 0.15$ & $1.57^{\mathrm{a}} \pm 0.31$ & $2.01^{\mathrm{a}} \pm 0.41$ & $3.27^{b} \pm 0.38$ \\
\hline Docosadienoic (C22:2) & $8.46 \pm 1.02$ & $8.01 \pm 0.08$ & $7.95 \pm 0.78$ & $7.49 \pm 0.78$ & $6.96 \pm 1.09$ \\
\hline Saturated fatty acids & $70.17^{c} \pm 1.13$ & $64.41^{b} \pm 1.52$ & $60.10^{\mathrm{a}} \pm 0.59$ & $61.50^{\mathrm{a}} \pm 1.51$ & $69.95^{c} \pm 0.90$ \\
\hline Mono unsaturated fatty acids & $18.26^{a} \pm 0.39$ & $23.32^{b} \pm 0.26$ & $30.36^{c} \pm 0.88$ & $28.97^{c} \pm 0.87$ & $19.82^{\mathrm{a}} \pm 0.48$ \\
\hline Poly unsaturated fatty acids & $11.55^{b} \pm 0.76$ & $11.26^{\mathrm{ab}} \pm 1.64$ & $9.52^{\mathrm{a}} \pm 1.47$ & $9.52^{\mathrm{a}} \pm 0.80$ & $10.23^{a b} \pm 1.38$ \\
\hline Unsaturated fatty acids & $29.82^{a} \pm 1.15$ & $34.59^{b} \pm 0.71$ & $38.49^{c} \pm 0.59$ & $39.89^{c} \pm 1.51$ & $30.05^{\mathrm{a}} \pm 0.90$ \\
\hline
\end{tabular}


Based on interpreted from the research data, galangal EO and pure cineole have different result on ruminal fatty acids. According to [18], the mechanism of action of essential oils is synergistic between bioactive compounds, so it does not only depend on the main compound. Cineole, the main component of galangal EO, also has almost the same activity as phenol in the presence of an ether group that is reactive in binding lipase and reduce the bacterial activity. According to [31] the effects of Achillea moschata essential oil and three main components were consisting of $d$ bornyl acetate (BOR), camphor (CAM), and eucalyptol (EUCA) have different effects on rumen microbes. Furthermore, [32] also reported that rumen bacteria would degrade the monoterpenes compounds during six hours of incubation. In this research, dosage of galangal EO is equal to $24 \%$ of cineole and similar results with [31] that cineole and A. moschata EO have different results on the rumen fermentation.

\section{CONCLUSION}

This study concluded that the optimal dose of galangal EO to decrease biohydrogenation and increase monounsaturated fatty acids as well as unsaturated fatty acid levels in the rumen was $60 \mu \mathrm{L}$.

\section{ACKNOWLEDGMENTS}

Thank you to the National Agency for the Extension and Development of Agricultural Human Resources, Ministry of Agriculture, Republic of Indonesia for giving the opportunity to continue a doctoral studies.

\section{REFERENCES}

[1] M. Tripathi, Effect of Nutrition on Production, Composition, Fatty acids and Nutraceutical Properties of Milk. Adv Dairy Res. 2015;02(02).

[2] M. Doreau and Y. Chilliard, Br. Digestion and metabolism of dietary fat in farm animals. Br J Nutr. 1997;78(1):S15-35.

[3] S. J. Lanier and B. A. Corl, hallenges in enriching milk fat with polyunsaturated fatty acids. J Anim Sci Biotechnol [Internet]. 2015;6(1):1-9. Available from: http://dx.doi.org/10.1186/s40104-015-00250

[4] O. Sytar, Z. Cai, M. Brestic, A. Kumar, M. N. V Prasad, N. Taran, S. Iryna, Garlic oil reduces ruminal fatty acid biohydrogenation in vitro. October. 2013;1-21. www.ejlst.com. European Journal of Lipid Science and Technolo
[5] M. Lourenço, E. Ramos-Morales, and R. J. Wallace, The role of microbes in rumen lipolysis and biohydrogenation and their manipulation. Animal. 2010;4(7):1008-23.

[6] F. Gadeyne, N. De Neve, B. Vlaeminck, and V. Fievez, State of the art in rumen lipid protection technologies and emerging interfacial protein cross-linking methods. Eur J Lipid Sci Technol. 2017;119(5):1-22.

[7] A. K. Patra and J. Saxena, Exploitation of dietary tannins to improve rumen metabolism and ruminant nutrition. J Sci Food Agric. 2011;91(1):24-37.

[8] V. Vasta, M. Daghio, A. Cappucci, A. Buccioni, A. Serra, C. Viti, and M. Mele, Invited review: Plant polyphenols and rumen microbiota responsible for fatty acid biohydrogenation, fiber digestion, and methane emission: Experimental evidence and methodological approaches. J Dairy Sci. 2019;102(5):3781-804. http://dx.doi.org/10.3168/jds.2018-14985

[9] A. Jayanegara, Ruminal Biohydrogenation pattern of poly-unsaturated fatty acids as influenced by dietary tannin. 2013. WARTAZOA Vol. 23 No. 1 Th.

[10] A. Jayanegara, M. Kreuzer, E. Wina, and F. Leiber, Significance of phenolic compounds in tropical forages for the ruminal bypass of polyunsaturated fatty acids and the appearance of biohydrogenation intermediates as examined in vitro. Anim Prod Sci. 2011;51(12):1127-36.

[11] A. I. Martinez-Gonzalez, E. Alvarez-Parrilla, Á. G. Díaz-Sánchez, L. A. de la Rosa, J. A. Núñez-Gastélum, A. A. Vazquez-Flores, and G. A. Gonzalez-Aguilar, In vitro inhibition of pancreatic lipase by polyphenols: A kinetic, Fluorescence spectroscopy and molecular docking study. Food Technol Biotechnol. 2017;55(4):519-30.

[12] V. Heidarian Miri, A. K. Tyagi, S. H. Ebrahimi, and M. Mohini, Effect of cumin (Cuminum cyminum) seed extract on milk fatty acid profile and methane emission in lactating goat. Small Rumin Res. 2013 Jun;113(1):66-72.

[13] D. Ye, S. K. R. Karnati, B. Wagner, J. L. Firkins, M. L. Eastridge, and J. M. Aldrich, Essential oil and monensin affect ruminal fermentation and the protozoal population in 
continuous culture. J Dairy Sci. 2018;101(6):5069-81.

[14] P. O. Eburu, S. Chikunya, M. I. Anya, and P. O. Ozung, Effects of rumen exposure to anise oil on ruminal fermentation and biohydrogenation of $\mathrm{N}-3$ polyunsaturated fatty acids. Glob J Pure Appl Sci. 2017;23(2):231.

[15] R. T. dan R. Young, Essential Oil SafetyRobert Tisserand. 2nd ed. Williamson EM, editor. London: Elsevier B.V; 2014. 1-780 p.

[16] M.L. Faleiro, The mode of antibacterial action of essential oils. Sci against Microb Pathog Commun Curr Res Technol Adv. 2011;3(3):1143-56.

[17] R. K. Verma, G. Mishra, P. Singh, K. K. Jha, and R. L. Khosa, Alpinia galanga - An Important Medicinal Plant: A review. Der Pharm Sin. 2011;2(1):142-54.

[18] J. Oonmetta-aree, T. Suzuki, P. Gasaluck, and G. Eumkeb, Antimicrobial properties and action of galangal (Alpinia galanga Linn.) on Staphylococcus aureus. LWT - Food Sci Technol. 2006;39(10):1214-20.

[19] A. P. Raina and Z. Abraham, Essential oil profiling of Alpinia species from southern India. Indian J Exp Biol. 2017;55(11):77681.

[20] X. Tang, C. Xu, Y. Yagiz, A. Simonne, and M. R. Marshall, hytochemical profiles, and antimicrobial and antioxidant activities of greater galangal [Alpinia galanga (Linn.) Swartz.] flowers. Food Chem 2018;255:3008. doi.org/10.1016/j.foodchem.2018.02.027

[21] Arun Dev Sharma* and Inderjeet Kaur, Eucalyptol (1,8 cineole) from eucalyptus essential oil a potential inhibitor of COVID 19 corona virus infection by Molecular docking studies. J Chem Inf Model. 2020;110(9):1689-99.

[22] G. K. Efruan, M. Martosupono, and F. S. Rondonuwu, . Review : Bioaktifitas Senyawa 1,8-Sineol pada Minyak Atsiri. Semin Nas Pendidik dan Saintek 2016 (ISSN 2557533X). 2016;2016:171-81.

[23] T. M. Al-thuwaini and M. B. S. Al-shuhaib, The Effects of Grass-Based versus GrainBased Feeding of Ruminants on the Human Hygienic Status , a Review. 2019;9(3):17480.
[24] V. Fievez, B. Vlaeminck, T. Jenkins, F. Enjalbert, and M. Doreau, Assessing rumen biohydrogenation and its manipulation in vivo, in vitro and in situ. Eur J Lipid Sci Technol. 2007;109(8):740-56.

[25] T. C. Jenkins, R. J. Wallace, P. J. Moate, and E. E. Mosley, Board-Invited Review: Recent advances in biohydrogenation of unsaturated fatty acids within the rumen microbial ecosystem. J Anim Sci. 2008;86(2):397-412.

[26] F. U. Hassan, H. M. Ebeid, Z. Tang, M. Li, L. Peng, K. Peng, X. Liang, and C. Yang, Front. A Mixed Phytogenic Modulates the Rumen Bacteria Composition and Milk Fatty Acid Profile of Water Buffaloes. Front Vet Sci. 2020;7(August):1-16

[27] L. Trends, International Journal of Advanced Research in Biological Sciences. 2014;1(3):81-93.

[28] G. Cobellis, Z. Yu, C. Forte, G. Acuti, and M. Trabalza-Marinucci, Dietary supplementation of Rosmarinus officinalis $\mathrm{L}$. leaves in sheep affects the abundance of rumen methanogens and other microbial populations. J Anim Sci Biotechnol [Internet]. 2016;7(1):1-8. Available from: http://dx.doi.org/10.1186/s40104-016-00868

[29] M. Kahvand and M. Malecky, Dose-response effects of sage (Salvia officinalis) and yarrow (Achillea millefolium) essential oils on rumen fermentation in vitro. Ann Anim Sci. 2018;18(1):125-42.

[30] H. Kim, E. Jung, H. G. Lee, B. Kim, S. Cho, S. Lee, I. Kwon, and J. Seo, Essential oil mixture on rumen fermentation and microbial community - An in vitro study. AsianAustralasian J Anim Sci. 2019;32(6):808-14.

[31]. S. Colombini, A. Rota, P. Parma, M. Iriti, S. Vitalini, C. Sarnataro, and M. Spanghero, Evaluation of dietary addition of 2 essential oils from Achillea moschata, or their components ( bornyl acetate , camphor , and eucalyptol ) on in vitro ruminal fermentation and microbial community composition. Anim Nutr. 2021 https://doi.org/10.1016/j.aninu.2020.11.001

[32] M. Malecky and L. P. Broudiscou, Disappearance of nine monoterpenes exposed in vitro to the rumen microflora of dairy goats: Effects of inoculum source, redox potential, and vancomycin. J Anim Sci. 2009;87(4):1366-73 